\title{
EVALUATION OF CRITICAL SUCCESS FACTORS THROUGH THE USE OF MIND MAP IN THE LOGISTIC PROCESS OF A CUSTOMS CLEARANCE COMMISSIONER IN A BRAZILIAN \\ COMPANY
}

Jadir P. dos Santos Universidade Nove de Julho (UNINOVE), Brazil

E-mail: jadir@uninove.br

Iris Bento da Silva Universidade de São Paulo (USP), Brazil

E-mail: ibs@sc.usp.br

Geraldo Cardoso de Oliveira Neto Universidade Nove de Julho (UNINOVE), Brazil

E-mail: geraldo.neto@uninove.br

Orlando Fontes Lima Junior Universidade de Campinas (UNICAMP), Brazil

E-mail: oflimaj@fec.unicamp.br

André Jacinto Nunes Universidade Nove de Julho (UNINOVE), Brazil E-mail: an.andrenunes@gmail.com

Submission: 31/10/2014 Accept: 15/11/2014

\section{ABSTRACT}

The objective of this work is to present, by the means of Mind Map, the critical success factors of the project developed by a Customs Clearance Commissioner. The research methodology used is exploratory, through interviews, based on the Delphi technique to obtain consensus, combined with the exploratory-descriptive analysis of a case study. The case study was observed in an unsystematic way, with an unstructured questionnaire. The conclusions presented here reveal two critical success factors in the import of parts and pieces, that are compounds of machines and industrial equipment, showing that the Mind Map is an innovative application for managing logistics projects, enabling better visualization of critical points, which 
brings improvements in the planning of activities for areas of knowledge, applied to the deployment project developed by the Customs Clearance Commissioner.

Keywords: project management; Mind Map; Customs Clearance Commissioner; logistics process.

\section{INTRODUCTION}

According to Kerzner (2004) in project management, planning requires creativity, in time, to the future. The planning shows stakeholders a view of the company as a whole, as there are several important internal and external variables that affect the strategy of an organization. Premises or assumptions of the planning regarding future conditions should be established, as they affect the environment of the organization.

Strengths, weaknesses, opportunities and threats, should also be analyzed to map responses for the improvement in supply (NATH; OZTUREN, 2013).

One can expect that companies that are not able to have a clear plan and vision of how to differentiate one from the other and are unique in what they do, are easily annihilated by contestants. Faced with so many changes that are occurring, any company that wants to succeed, must adjust its profile to meet strategic planning (PORTER, 1990, 2000; MINTZBERG, 1994).

Furthermore, this work shows the application of the Mind Map (BUZZAN, 1995) for project management in a logistic process, as it is a proposed innovation in customs clearance.

Once the research question is placed, it is emphasized that the goal of this work is to develop a method of applying logistic Mind Map combined with project management applied to a clearance commissioner.

Based on these points, the development of this work was directed by the following research question: Q1: How to reconcile the application of project management and the Mind Map assessment of critical success factors in the logistic process of a customs clearance commissioner?

The application of this methodology was demonstrated in a qualitative study on a logistic process of customs clearance on an implementation project of a company in Brazil. 
This paper is structured as the following. Initially, Section 2 presents a theoretical framework for Supply Chain Management, Mind Map, Project Management and Technical Delphi. Section 3 presents the methodology. Then, in section 4, a case study of the project management and Mind Map combined is presented. In Section 5, the case presented is analyzed in light of the research questions and, finally, section 6 presents the conclusions of work.

\section{THEORETICAL REFERENCE}

\subsection{Supply Chain Management (SCM) and Logistics}

Businesses are increasingly seeking excellence to achieve greater levels of efficiency and effectiveness. Thus, this fact implies leveraging logistics management system and evaluate the effectiveness outsource testing (CALAZANS et al., 2012; LUMMUS; VOKURA, 1999; MENTZER et al., 2001; SAMARANAYKE, 2005).

According to Ballou et al. (2000), Fawcett and Magnan (2002), and Arshinder Deshmuk (2008) the strategy of SCM is seeking cost reduction, because the products are manufactured, ever more in different countries where they are consumed today. In addition, the process can be mapped by the value stream, setting opportunities to eliminate waste; but the implementation of action plans to achieve those outcomes should override the changes in organizations.

SCM is already much more than a synonym for logistics. It includes the management of all activities involved in identifying suppliers, purchasing, manufacturing, operations and logistics. It also integrates the supply and demand management between firms within the supply chain (BALLOU et al., 2000; BARRATT, 2004; ARSHINDER; DESHMUK, 2008).

From this point of view, the challenge of globalization makes supply chain management change for an issue that goes beyond national borders - customs clearance. This type of order includes geographical distances that cause an increase in logistics costs to improve customer service (BAINES; LIGHTFOO, 2014; HAN; GOOI, 2006; TAKEDA et al., 2008; OZGEN; TANYAS, 2011; PAULRAJ; ARLBJORN, 2013).

Customs Clearance Commissioners engages in the foreign trade area, coordinating and supervising the services with other companies that are competent 
to operate in cargo areas: customs, infra-aero and other load depositories. And, also operates with the customs clearance. It is also important to make risk analysis (GARCIA; WEISSERB, 2006; COELHO; LEE, 2008; CAl et al., 2009; KONONEMA et al., 2011).

\subsection{Mind Map}

Mind Map is a tool used to arrange thoughts; it can be the expression of radial thought and a graphical technique that provides the key to unlock the potential of the human brain. The Mind Map can be applied to any aspect of life in which the development of learning and clarity of reasoning can improve the performance of the human being (BUZAN, 1995; BREDILET, 2008; CLAUSS et al., 2013).

It is also important to inform that the characteristics of the Mind Map, are not the use of subject records formatted into sentences, in other words, a sentence is not necessary to explain the topic or sub-topic treated in time, due to the form in which it is adopted, because the important thing is the keyword of the subject, image linked, to facilitate memorization (EPPLER, 2006; BERDIE, 2009).

Each branch of Mind Map works as a multiplier, with exponential amplification possibilities. According Buzzan $(1974,2005)$, this is where the intangibles such as ideas, information and relationships, become tangible and applicable to project management.

Among the many benefits of Mind Map, Buzan (1995), Eppler (2006) and Peneder (2008) point out the following: pleasing to be seen; reading, enjoying and remembering; being more creative; saving time; solving problems; concentrating; organizing and clarifying thoughts; remembering best; studying with greater speed and efficiency; making the studies more enjoyable; planning; communicating and surviving.

\subsubsection{A conceptual comparison between methods of knowledge construction}

In the planning process there are several cognitive tools, Eppler (2006) made a comparison between four of them: concept map, mind maps, conceptual diagrams, and visual metaphors. Comparing the tools (Table 1), one sees that they have 
benefits by applying visual mapping techniques that stimulate the graphical reconstruction of knowledge in a positive way.

Table 1: A comparison of concept maps, mind maps, conceptual diagrams, and visual metaphors

\begin{tabular}{|c|c|c|c|c|}
\hline $\begin{array}{c}\text { Format } \\
\text { Parameters }\end{array}$ & $\begin{array}{c}\text { Concept map (J.D } \\
\text { Novak) }\end{array}$ & $\begin{array}{c}\text { Mind map }(T . \\
\text { Buzan) }\end{array}$ & $\begin{array}{c}\text { Conceptual } \\
\text { diagram }\end{array}$ & Visual metaphor \\
\hline $\begin{array}{l}\text { Sample } \\
\text { thumbnail } \\
\text { representation }\end{array}$ & 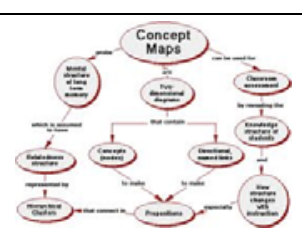 & & 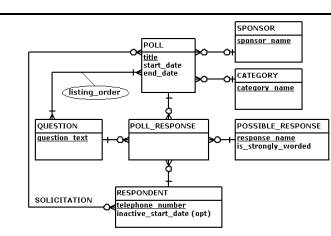 & 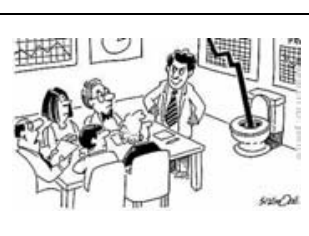 \\
\hline Definition & $\begin{array}{l}\text { A concept map is } \\
\text { a top-down } \\
\text { diagram showing } \\
\text { the relation- ships } \\
\text { between } \\
\text { concepts, } \\
\text { including cross } \\
\text { connections } \\
\text { among concepts, } \\
\text { and their } \\
\text { manifestations } \\
\text { (examples). }\end{array}$ & $\begin{array}{l}\text { mind map is a } \\
\text { multi- coloured and } \\
\text { image- centred, } \\
\text { radial diagram that } \\
\text { represents seman- } \\
\text { tic or other connec- } \\
\text { tions between } \\
\text { portions of learned } \\
\text { material } \\
\text { hierarchically. }\end{array}$ & $\begin{array}{l}\text { A conceptual } \\
\text { diagram is a } \\
\text { systematic } \\
\text { depiction of an } \\
\text { abstract concept in } \\
\text { pre-defined } \\
\text { category boxes with } \\
\text { specified } \\
\text { relationships, } \\
\text { typically based on a } \\
\text { theory or model. }\end{array}$ & $\begin{array}{l}\text { A visual metaphor } \\
\text { is a graphic } \\
\text { structure that } \\
\text { uses the shape } \\
\text { and elements of a } \\
\text { familiar natural or } \\
\text { manmade artefact } \\
\text { or of an easily } \\
\text { recognizable } \\
\text { activity or story to } \\
\text { organize content } \\
\text { meaningfully and } \\
\text { use the } \\
\text { associations with } \\
\text { the metaphor to } \\
\text { convey additional } \\
\text { meaning about } \\
\text { the content. }\end{array}$ \\
\hline $\begin{array}{l}\text { Main function } \\
\text { or benefit }\end{array}$ & $\begin{array}{l}\text { Shows systematic } \\
\text { relationships } \\
\text { among sub- } \\
\text { concepts relating } \\
\text { to one main } \\
\text { concept. }\end{array}$ & $\begin{array}{l}\text { Show sub-topics of } \\
\text { a domain in a } \\
\text { creative and } \\
\text { seamless manner. }\end{array}$ & $\begin{array}{l}\text { Analyze a topic or } \\
\text { situation through a } \\
\text { proven analytic } \\
\text { framework. }\end{array}$ & $\begin{array}{l}\text { Organize content } \\
\text { meaningfully and } \\
\text { convey main } \\
\text { message about it. }\end{array}$ \\
\hline $\begin{array}{l}\text { Application } \\
\text { guidelines }\end{array}$ & $\begin{array}{l}\text { Use it as a } \\
\text { learning support } \\
\text { tool for students, } \\
\text { that is, to } \\
\text { summarize key } \\
\text { course topics or } \\
\text { clarify the } \\
\text { elements and } \\
\text { examples of an } \\
\text { abstract concept. }\end{array}$ & $\begin{array}{l}\text { Use it for pre- } \\
\text { analytic idea jostles } \\
\text { or rapid note- } \\
\text { taking, or to } \\
\text { structure the main } \\
\text { contents of a } \\
\text { course or topic } \\
\text { hierarchically. }\end{array}$ & $\begin{array}{l}\text { Use it to structure a } \\
\text { complex topic with } \\
\text { the help of pre- } \\
\text { defined categories. }\end{array}$ & $\begin{array}{l}\text { Use it to } \\
\text { memorize the key } \\
\text { elements of a } \\
\text { method or } \\
\text { concept by } \\
\text { placing them } \\
\text { meaning- fully } \\
\text { within a fitting } \\
\text { graphic metaphor } \\
\text { that shares one or } \\
\text { more properties } \\
\text { with the topic. }\end{array}$ \\
\hline
\end{tabular}


Table 2 presents an overview of Table 1, namely the advantages and disadvantages of the four displayed formats.

This work uses the "Mind Map" through the program free mind, as for the disadvantages of applying Mind Map's, they were minimized, because the project participants were directly involved in the preparation of mental maps and / or were communicated at meetings about the proposed changes, thus reducing its complexity. Furthermore, the application of the "Mind Map" in a customs clearance commissioner is beneficial in relation to rapid systemic vision, by facilitating the missing analysis of the project activities through mental mapping details of the activities and for being easily didactic applied in the logistics sector.

Table 2 - Advantages and disadvantages of the four visualization formats

\begin{tabular}{|c|c|c|c|c|}
\hline $\begin{array}{c}\text { Format } \\
\text { Parameters }\end{array}$ & $\begin{array}{c}\text { Concept map (J.D } \\
\text { Novak) }\end{array}$ & $\begin{array}{l}\text { Mind map (T. } \\
\text { Buzan) }\end{array}$ & $\begin{array}{c}\text { Conceptual } \\
\text { diagram }\end{array}$ & Visual metaphor \\
\hline $\begin{array}{l}\text { Main } \\
\text { advantages }\end{array}$ & $\begin{array}{l}\text { 1. Rapid } \\
\text { information } \\
\text { provision. } \\
\text { 2. Systematic, } \\
\text { proven approach to } \\
\text { provide overview. } \\
\text { 3. Emphasizes } \\
\text { relation- ships a.nd } \\
\text { connections among } \\
\text { concepts. } \\
\text { 4. Ability to assess } \\
\text { quality of concept } \\
\text { map through } \\
\text { evaluation rules. }\end{array}$ & $\begin{array}{l}\text { 1. Easy to learn } \\
\text { and apply. } \\
\text { 2. Encourages } \\
\text { creativity and } \\
\text { self-expression. } \\
\text { 3. Provides a } \\
\text { concise hierar- } \\
\text { chic overview. } \\
\text { 4. Easy to } \\
\text { extend and add } \\
\text { further content. }\end{array}$ & $\begin{array}{l}\text { 1. Provides a } \\
\text { concise overview. } \\
\text { 2. Structures a } \\
\text { topic into } \\
\text { systematic building } \\
\text { blocks. } \\
\text { 3. Assures that } \\
\text { main aspects are } \\
\text { considered. } \\
\text { 4. Can be applied } \\
\text { to a variety of situa- } \\
\text { tions in the same } \\
\text { manner. }\end{array}$ & $\begin{array}{l}\text { 1. Serves as a } \\
\text { mnemonic aid } \\
\text { (method loci). } \\
\text { 2. Draws attention } \\
\text { and in spires } \\
\text { curiosity. } \\
\text { 3. Activates prior } \\
\text { knowledge about } \\
\text { metaphor } \\
\text { domain. } \\
\text { 4. Facilitates } \\
\text { understanding by } \\
\text { triggering } \\
\text { functional } \\
\text { associations. }\end{array}$ \\
\hline $\begin{array}{l}\text { Main } \\
\text { disadvantages }\end{array}$ & $\begin{array}{l}\text { 1. Not easy to } \\
\text { apply by novices; } \\
\text { requires extensive } \\
\text { training. } \\
\text { 2. Concept maps } \\
\text { tend to be } \\
\text { idiosyncratic. } \\
\text { 3. Time consuming } \\
\text { evaluation through } \\
\text { tutors. } \\
\text { 4. The overall } \\
\text { pattern does not } \\
\text { necessarily assist } \\
\text { memorability. }\end{array}$ & $\begin{array}{l}\text { 1. Idiosyncratic, } \\
\text { hard to read for } \\
\text { others. } \\
2 \text {. Represents } \\
\text { mostly } \\
\text { hierarchic } \\
\text { relationships. } \\
\text { 3. Can be } \\
\text { inconsistent. } \\
\text { 4. Can become } \\
\text { overly complex } \\
\text { (loss of big } \\
\text { picture). }\end{array}$ & $\begin{array}{l}\text { 1. Can be difficult to } \\
\text { understand without } \\
\text { knowledge of } \\
\text { category meanings. } \\
\text { 2. May not be appli- } \\
\text { cable to the topic at } \\
\text { hand. } \\
\text { 3. Does not provide } \\
\text { mnemonic help } 4 \text {. } \\
\text { Does not foster } \\
\text { creativity or self- } \\
\text { expression. }\end{array}$ & $\begin{array}{l}\text { 1. Cannot easily be } \\
\text { extended or } \\
\text { modified. } \\
2 \text {. May be } \\
\text { misunderstood, } \\
\text { may trigger wrong } \\
\text { associations. } \\
\text { 3. Can be difficult } \\
\text { to draw (rapidly). } \\
\text { 4. Can be } \\
\text { manipulative or } \\
\text { misunderstood. }\end{array}$ \\
\hline
\end{tabular}

Source: Eppler, 2006. 


\subsection{Project management}

In the bibliography there are several definitions for the project because the understanding of the project is different to each individual that defines it (OJIAKO et al. 2011). PMBOK - Project Management Body of Knowledge defines it as: "A project is a temporary endeavor undertaken to create a product, service or result" (KERZNER, 2004; JOHNSON, 2013).

It can be defined based on citations of previous authors that the project is a temporary endeavor, with beginning, middle and end set to create a unique product or something. The project will be finalized when the delivery of what was planned is made (LEWIS, 2000; GAREL, 2012).

The context of project management consists of nine knowledge areas are: Integration; scope; time; cost; quality; Human Resources; communication; risk; Acquisitions (FORTUNE; WHITE, 2006; MARQUES et al., 2010;. REICH et al., 2012; YAGHOOTKAR; GIL, 2012). In figure 1 it is shown how this connection is in management areas, and in Figure 2, how these areas would be with the concept of Mind map.

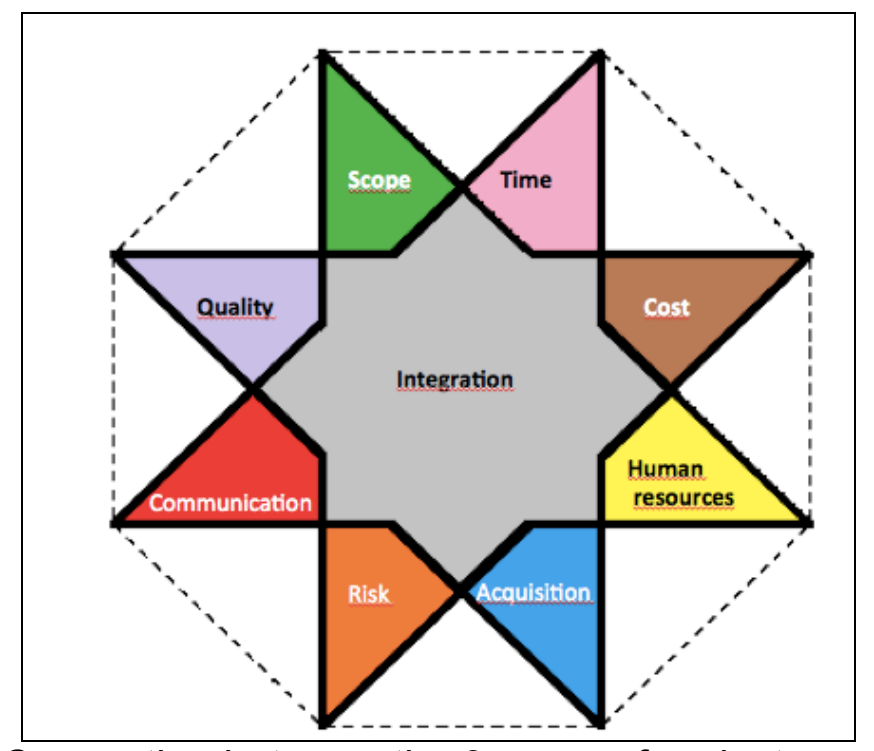

Figure 1: Connection between the 9 areas of project management.

\section{METHODOLOGY}

Every thought begins with a problem. Those who are not able to perceive and formulate problems clearly cannot do science (Rosenbaum and Rubin, 1983). This 
paper evaluates the application of the Mind Map for the critical factors of logistics process of a customs clearance project to establish a company in Brazil.

Qualitative research is multi-methodological about the focus, involving an interpretive, naturalistic approach to its subject. This means that qualitative researchers study things in their natural setting, attempting to make sense of, or interpret phenomena in terms of meanings people bring to them (EISENHARDT, 1989).

The role of the methodology is to conduct the research in accordance with the requirements, scientific (GLASER; STRAUSS, 1967). Looking to show some of the specificities of the research, in terms of forms of reasoning, stating that the argumentative (or deliberative) nature of the proceedings is explicitly recognized, contrary to the traditional conception of the research, in which are valued logicalformal and statistical criteria. To meet these precepts we used the following methodology (YIN, 1994):

1. We started with the definition of a relevant application of mind map and the knowledge areas of PMI (Project Management Institute), depending on the theme: sustainability; importance; originality;

2. The method of a scientific discipline is its own intrinsic form of thinking and knowing. Therefore, The theoretical reference, with which the researcher works and through whom he received his training is of great importance, therefore, a research was carried out on project management, Mind Map and Delphi technique;

3. We applied a questionnaire for consensus (structured) to the company's board and its staff as an application of the Delphi technique, and set up the critical success factors for a project to set up a business in Brazil;

4. Presentation of the case study (descriptive);

5. The corresponding areas of project management were applied in the form of Mind Map;

6. There was reflection on the problem and use the Mind Map, and how to apply it in the knowledge areas of PMI, to favor a logistics project. 
The item numbers 3 to 5 were performed in parallel. This methodology is presented in Figure 2 below.

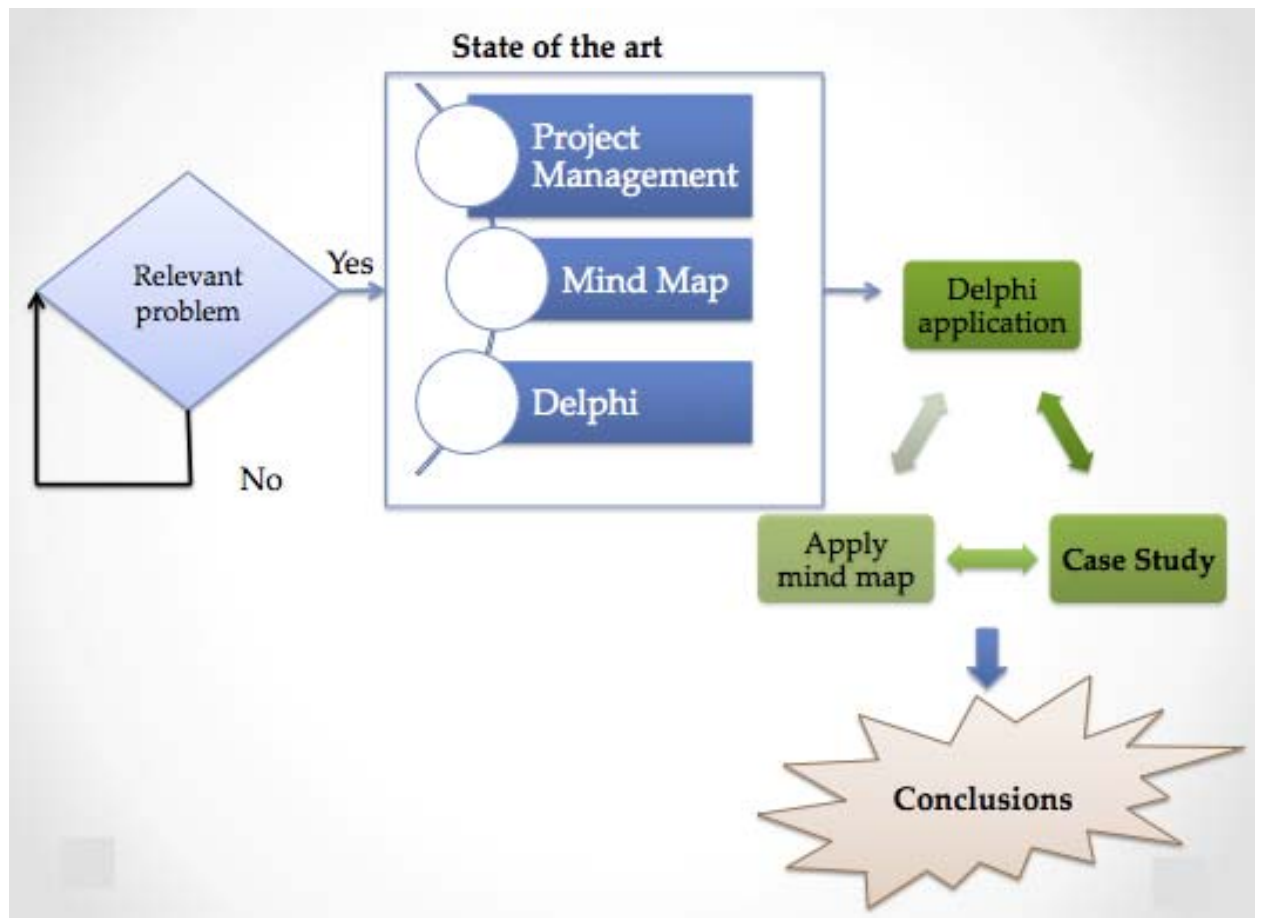

Figure 2: Methodology applied.

\section{CASE STUDY}

\subsection{Characterization of the enterprise}

First, before beginning, one should clarify that companies that will be worked on this case study will receive fictitious names of Spratill, for the company will implement a factory in Brazil, and GeoComex, representing the customs clearance commissioner (see figure 3).

The business group GeoComex with over 35 years of world-renowned company active in international market, was one of the protagonists on International Shipping and Customs Clearance industry in South America, and in Brazil since 1994 has distinguished itself from other Customs Clearance Commissioner for not selling just order, and also a degree of quality and excellence of its professional and service, treating customers as unique. Here we highlight the provision of service (JAYRAM; TAN, 2010; RODRIGUES, 2012; CARTER, 2013).

The company Spratill, which gave research basis is comprised of more than 40 branches already established in Brazil, working with natural resources and energy, agricultural products such as grain, fertilizers, petrochemicals, metals and 
various other areas. It performs the processing, transportation and marketing among other activities. With more than 20 years since it was formed, operates in more than 140 locations, with more than 15000 employees in more than 70 nationalities. Actively participates in philanthropic activities on Brazil in favor of orphans, as well as over five environmental projects in the world, to balance the emission of carbon and other activities in different areas.

\subsection{Development and its phases}

The case study below will elaborate the composition of two phases, namely, will be divided in two sides of studies. The first side will have the vision of GeoComex Customs Clearance Commissioner, and the second side is the Spratill Company and the view that the Commissioner had and has of this side, since you cannot have access to the company and the people involved. The division into parts of the case study will be as follows: The first phase will address issues related to the Customs Clearance Commissioner, in other words, how it came to the implementation of the logistics project of the company in Brazil, as well as the of study of the project in order to develop a proposal, also, the people involved and other issues that will be addressed and will be part of the research for consensus achievement, which will be analyzed and mapped. It can be observed in Figure 3 some of the steps that will be addressed during the case study, taken from the development of the project undertaken.

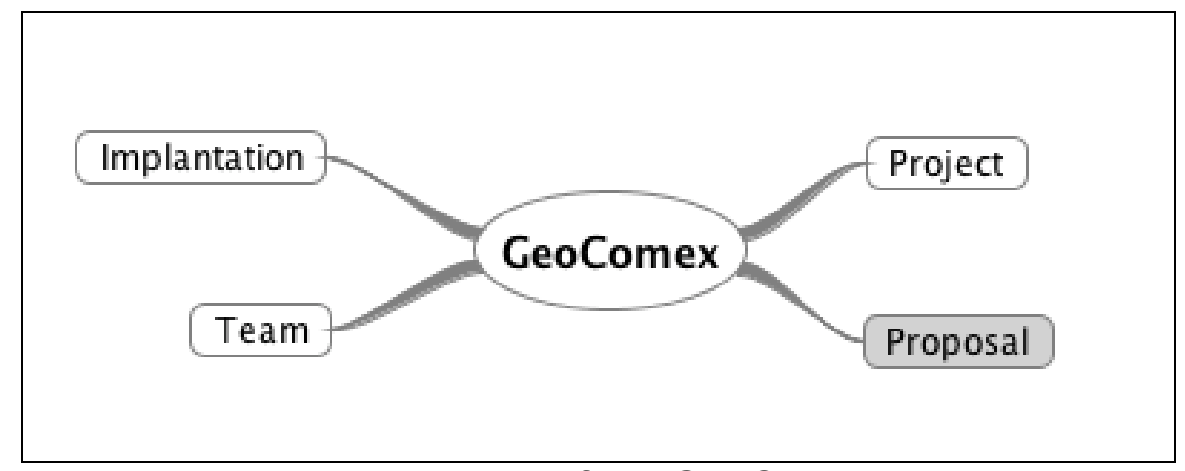

Figure 3: Initial Flow of the GeoComex project.

The second phase of the case study will address since prior to acceptance of the Spratill company proposal through delivery, as the phase of the project which the GeoComex company is responsible for is scheduled for completion in early March 2013. Within this phase, the project is planning to bring in machinery, equipment and accessories quickly and without loss of merchandise which will compose the 
installation of the company, according to the schedule, and even the identification and neutralization of unnecessary expenses. Other issues relevant to the project wil also be addressed. A brief description of the planning Spratill, seen by the company GeoComex is presented in figure 4 .

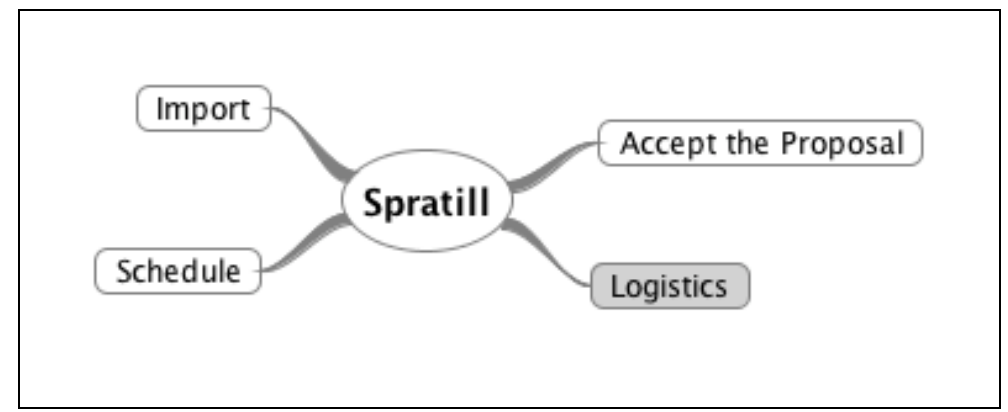

Figure 4: Initial Flow Spratill.

Evaluations will be made on the nine knowledge areas of the project management combined with Mind Map. In the flow of Figure 5 there is a brief demonstration of how it will be done throughout the case study, such as the mapping of the processes developed.

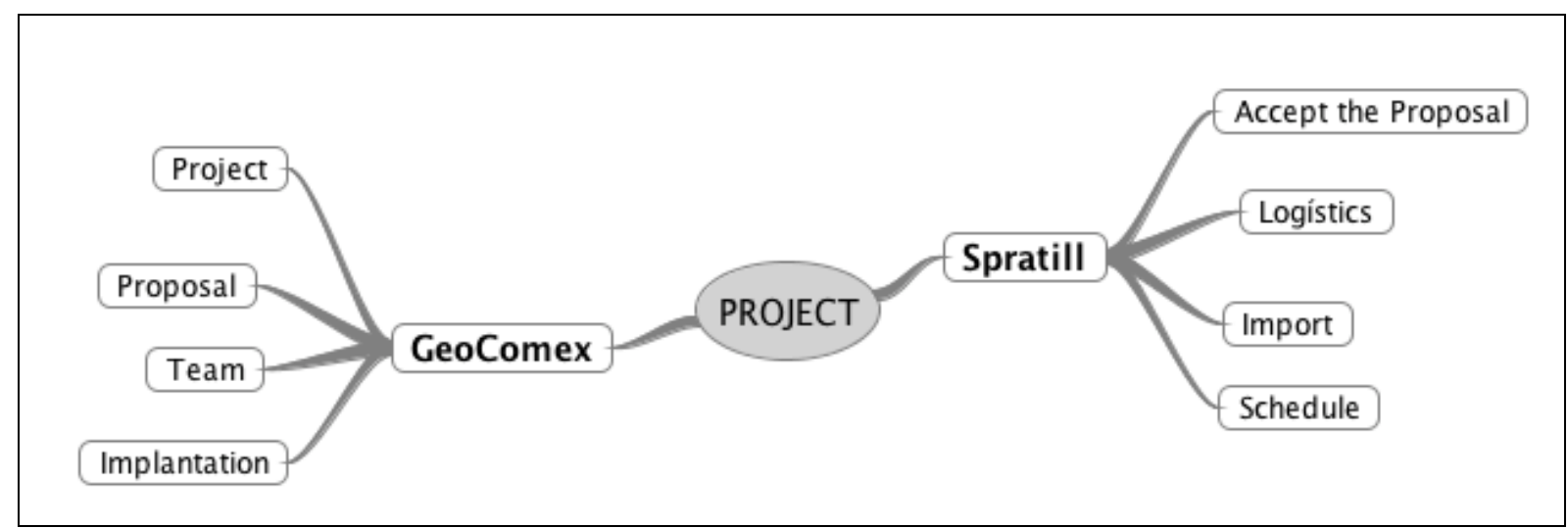

Figure 5: Flow project separating the first phase from the second phase.

Delphi technique was used to reach the critical success factors, these factors are named with consensus, which are the main processes to be analyzed and mapped.

The first part of the case study presents Figure 6, which shows the flow of the initial procedures developed by GeoComex. It is not a stream with all stages developed, but most of the main parts of which will be removed for the consensus analysis. 


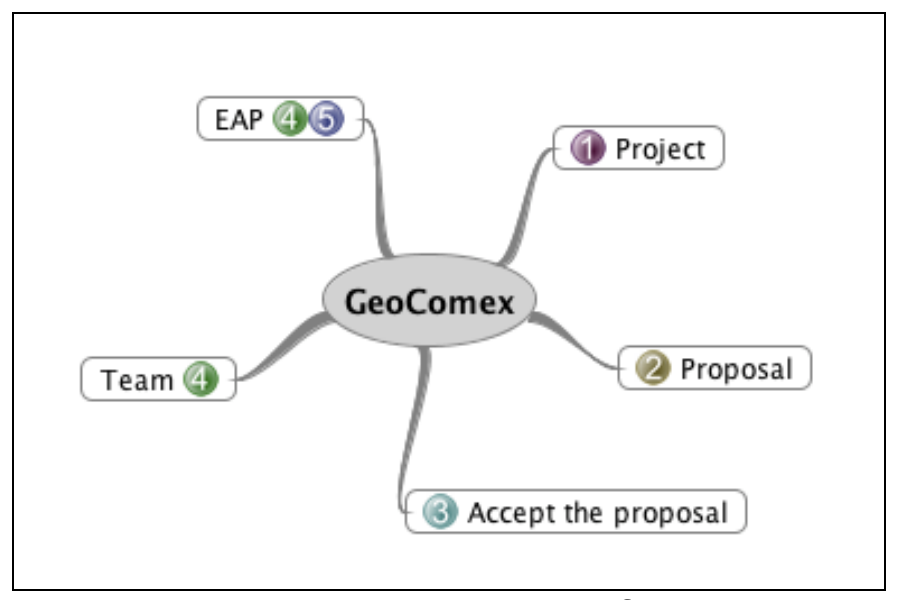

Figure 6: Project initial flow.

It is observed in Figure 8, which is highlighted in colored numbers. They are used to inform the order of activities and their dependencies, i.e., you cannot prepare a proposal without knowing to whom it is dedicated, therefore it is critical to have information about the project, what is its purpose, what is the due date for achievement, among others. The proposal developed to meet this project was composed for the two phases. The first phase involves working to bring the parts and pieces that made up the machinery and the second phase is delivery to the desired location.

The beginning of the first phase of the project consisted of the locations from where the goods are brought, in other words, by being multimodal operations that would be coming through the port of Santos and the borders of the country, which could be by Uruguayana, Foz do Iguaçu, São Borja and / or Corumbá to understand the company's needs. (Here, a map showing the cities could be placed)

The importance and need of the mode enabled for the company was highlighted. Thus the company was habilitated in the Common modality, since the company would be making operations in foreign trade, which should exceed the amount of $\$ 150$ thousand US dollars or the equivalent in another currency for imports CIF (Cost, Insurance and Freight), as the simplified mode is defined for minor imports, in section II, paragraph 2, of Art. 2. And three hundred thousand US dollars or the equivalent in another currency for FOB (Free on Board) exports, the Normative Ruling of the Federal Revenue 650/2006. 
For the parts and pieces that came from Asia and Europe, the company was already aware that depending on the size of the ship, it would not be possible to enter the same port of Santos, therefore it would be necessary to transship the goods.

A team was structured after project acceptance, with seven employees of the GeoComex Company, who became the project cell. Other employees would help, with partners in each region with operations. The members of the project cell team were selected based on experience.

A team of professionals with different levels of experience was structured. In the meantime, Spratill had structured their team to develop the project, but many of the people who composed this team did not have the knowledge needed for a large operation, resulting in the delay of preparation and submission of documents for analysis and confirmation of shipment authorization.

The proposed expenses were not included, which could arise, such as: trips to borders and abroad, as well as other costs that this would entail, such as lodging, meals and others, reporting this situation to Spratill, and the need for personal monitoring to fix it, sending all the expenses that would have separate billing, where the company never objected to authorize travel and expenses.

Planning regular meetings to know the status of the case, issues and other matters of the project, was also not included. The meetings took place according to need, not planning or taking notes on what to be spoken.

The proposal developed to meet this project was composed of more than one phase, i.e., the Spratill has several suppliers, so the GeoComex would have different processes for monitoring.

\subsection{Delphi technique}

Based on what was defined in the Delphi technique, the same was applied to produce project information, this information has been filtered so that it was possible to obtain the consensus of the project (Table 3). The consensus is the critical success key factors of the project that will be mapped by the Mind Map. 
Table 3: Application of the Delphi Technique.

\begin{tabular}{|c|c|c|c|c|c|}
\hline $\begin{array}{l}\text { Companies } \\
\text { involved }\end{array}$ & Process & 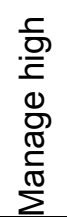 & $\begin{array}{l}\mathbb{0} \\
\stackrel{\mathbb{D}}{\mathbb{E}} \\
\stackrel{\mathbb{\pi}}{\Sigma}\end{array}$ & $\begin{array}{l}\bar{\pi} \\
\frac{0}{0} \\
\stackrel{0}{\pi} \\
\frac{\pi}{0} \\
\frac{0}{0}\end{array}$ & Total \\
\hline GeoComex & A- Conquer the customer & 3 & 2 & & 5 \\
\hline GeoComex & B- Structuring a team & 3 & & & 3 \\
\hline GeoComex & C- First operation & 3 & 2 & 1 & 6 \\
\hline GeoComex & D- Second operation & 3 & 2 & 1 & 6 \\
\hline Spratill & E- Financial conditions & & 2 & & 2 \\
\hline GeoComex & F- Complicated logistics & & & 2 & 1 \\
\hline
\end{tabular}

Source: The authors.

Table 3 shows the processes started and the company that is responsible for them. The experts of the project, who contributed on the research highlighted the keys for project success, so each expert had the burden of reaching consensus. After a few group meetings we had two consensuses that will be addressed in the main processes to be analyzed and mapped.

\subsection{Implementation}

The consensuses obtained are the critical success key factors of the project that will be mapping the Mind Map, analyzed and considered as First and Second Operation. The two operations performed by the port of Santos moved 76 containers of 40 ', and 2 containers of 20', considering only the first shipment of parts. These operations were analyzed in the nine knowledge areas with the principles of Mind Map, resulting in important observations within the process obtained as consensus, and mapped. For each of these operations, there is a petition to request the Secretariat of the Federal Revenue of Brazil, which asks permission to the Federal Revenue of Brazil, in the city where the factory is being installed, so that only one Import Declaration is made, for more than one bill of lading, due to the volume and weight to be carried by a multimodal operation, combining transport by river and road environment, which flow a significant amount of trucks.

A full inspection of goods was requested in the whole establishment of the importer, and that there may possibly be escorting by convoy and the Federal Highway Police at certain stretches / federal highways, due to having forged parts and large parts that have excess height and width. 
The petition request for a conference at the site of the applicant should be made according to the dimensions, however, in the Declaration of Tax registration a classification of the complete machinery or equipment has been made, i.e., the company agreed to assemble the machine or equipment to make a conference in accordance with Statement of Taxes.

This is based on the Normative Ruling of the Federal Revenue in 680/2006, Article 35, Items I and III, combined with Articles 47 and 68, item I, paragraphs a and $\mathrm{b}$, thus proving that there was a correct classification, and consequent payment of customs taxes, plus the perfect description and identification system for customs clearance.

After the arrival of goods at the port of Santos, they were being cleared for carriage, and then left in groups. There were some problems to release the trucks when they arrived in the destined city, for example, in which the rain made it impossible to return to the place of taxation for inspection and release, so drivers had to wait, which delayed the next group, therefore, many of the trucks had to return and recharge for the next release, which occurred around 4 days, depending on the date scheduled for tax inspection.

The Spratill Company provided an aircraft to transport the inspectors appointed by the Section of Customs Control for monitoring, from the city where the auditors were to the GeoComex plant, but there were fiscals, who refused to, prefer to use the IRS cars. It wasn't only the operations that entered the port of Santos who had transportation and conferencing problems. Also, the operations carried out by border also had problems, as an example, there a delay in the machines that were in waterway transportation by the International Freight and Customs Transit Declaration Manifest, due to drought in the region, the draft of the barges were getting stuck; thus, the operation had a delay of three months. Eventually, it was necessary to wait for the rains to continue the navigation.

\section{a) First Operation}

The first operation (not due to sequential mode of transport) began importing in early December 2011. This operation was of the parts and pieces from a country in Latin America, which used multimodality, on road with trucks, river barges and ending on road with trucks. These parts and pieces, has a set of machines which 
came dismembered due to the size and weight which corresponds to approximately 1,360 tones (gross weight). A period of 120 days was established for this operation, from the start date. The critical factors for the success of this first project process were:

\section{a.1) Scope}

In Figure 7, it is drafted in the Mind Map the factors described in the scope of this first process, evaluated and analyzed, and can be seen how information leads to other information. In this area of logistics, since the departure of the goods from the manufacturer to the importer, was all prepared by the exporter, resulting in only one monitoring path and negotiation on arrival of the goods in the country with the tax, it was only possible with the departure of the CEO and coordinator GeoComex, in which the fiscal ended up doing the same release of merchandise without sail, which goes against the conduct of the same.

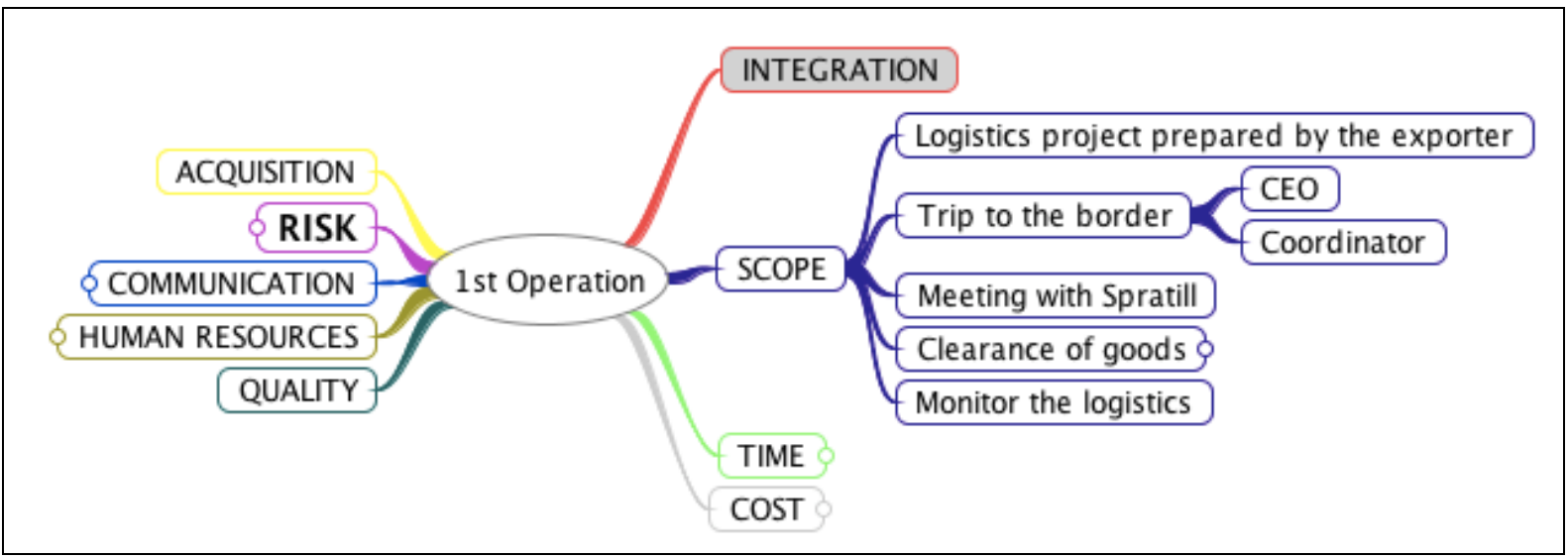

Figure 7: Scope Flow of the first process.

\section{a.2) Time}

The flow of the activities occurring in the area of time can be seen in figure 8 , which shows the connection information with other areas, such as the inclusion of an extra time in scope with the activity of the barges removal of merchandise. As there wasn $1 \mathrm{t}$ this time, it resulted in the delay in the project as a whole.

As for time, planned by Spratill and what has been accomplished, one realizes that the company did not include extra time, i.e., the company planned so that there could be delays, which resulted in only about three months delivery delay, because it was stranded in the river, waiting for the rains to return the river to fill and so continue the journey. 
Another step that had great impact on the delay of the schedule prepared by Spratill was lack of land preparation, i.e., it was not flat nor with other needs in order to receive the parts and pieces of machinery and equipment. Figure 8: Time Flow of first process.

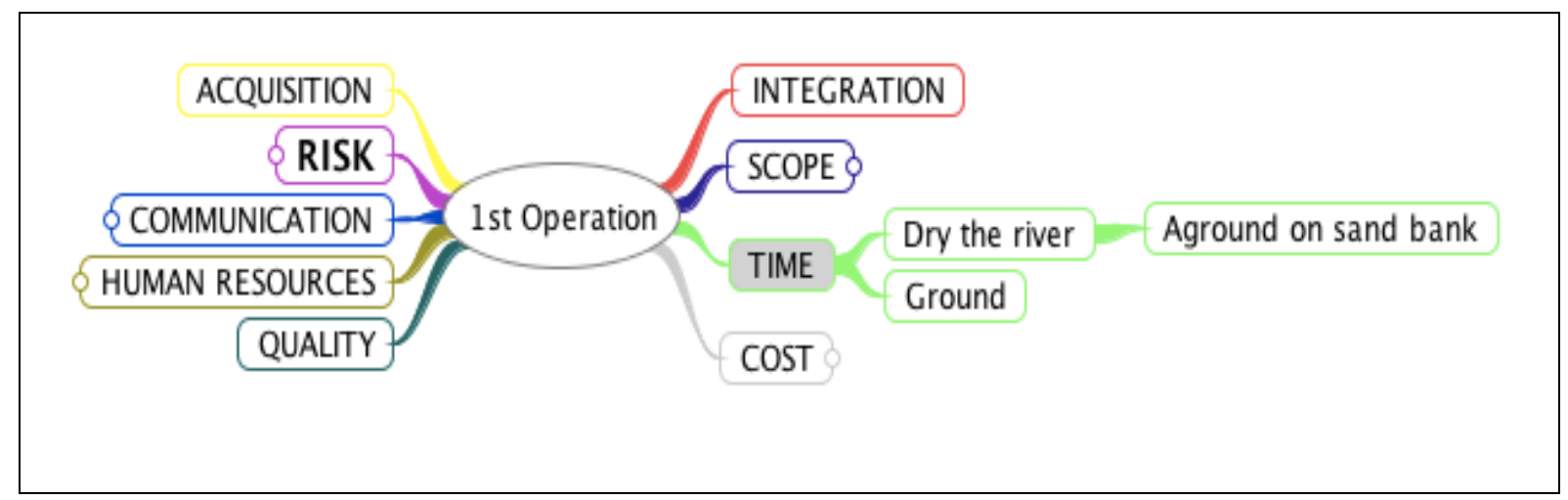

Figure 8: Flow of Time first process.

\section{a.3) Costs}

In Figure 9 is presented a more complete analysis, GeoComex did every part of logistics held so far under the control of the exporter, so there was a more detailed follow-up and an expected result, but it could not have occurred because they forgot this step in the schedule.

As the company had not planned to include additional time in the schedule, it did not include expenses that could occur. Delayed Merchandise that got stranded due to drought, unusual at the time, Spratill had no preventive, but corrective action.

It is within that area the result of miscommunication early in the project where GeoComex did not know the logistics had been made by the exporter, this resulted in the need to personally check what was happening with the merchandise.

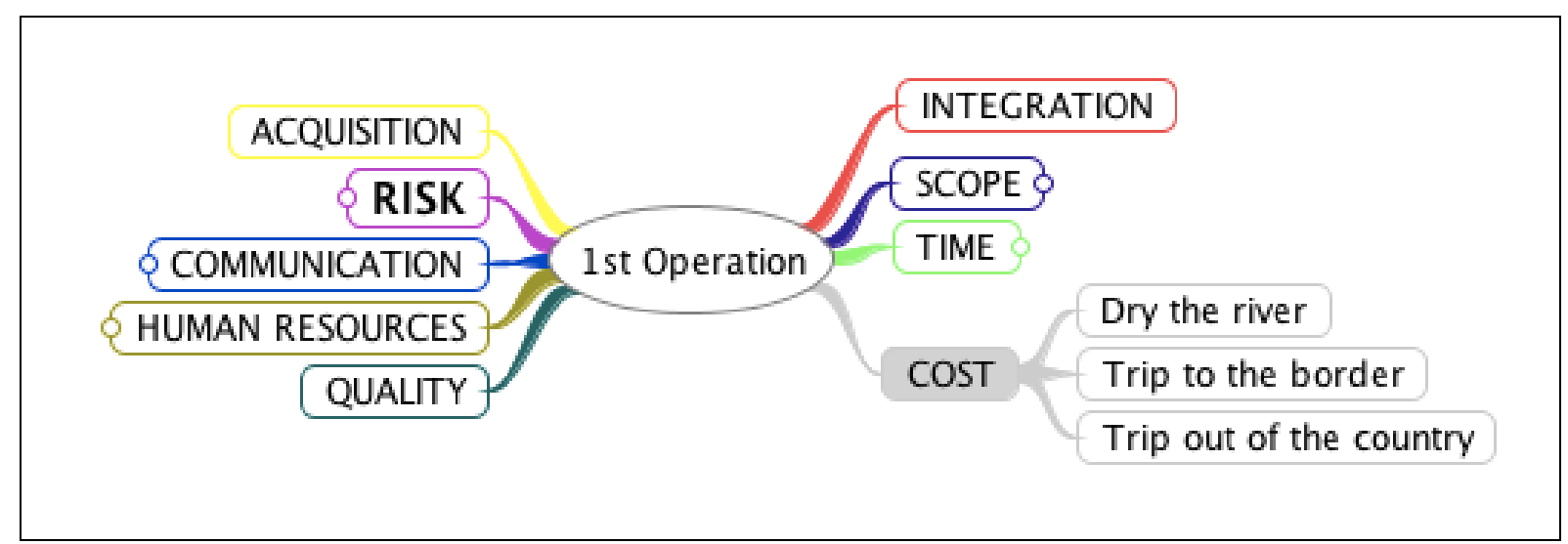

Figure 9: Flow Cost of the first process. 


\section{a.4) Human Resources}

Figure 10 shows the relationship of the first operation with those obtained and motivated, human resources is presented based on the feedback information, which took a while to come. This occurred when the Spratill team was requested some information, because of lack of information concerning the operation in progress. Thus, the schedule was not completely impaired, but there was some delay at the beginning.

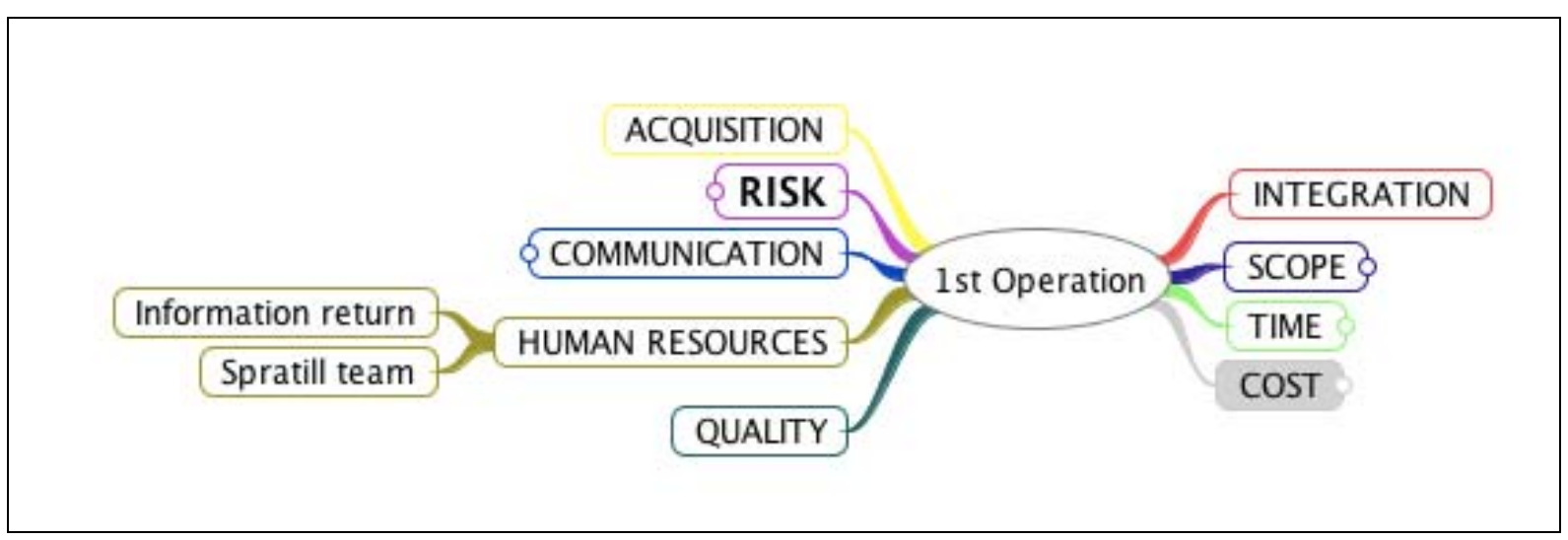

Figure 10: Human Resources flow of the first process.

\section{a.5) Communication}

Figure 11 identifies some of the critical key factors, such as lack of communicating between Spratill and GeoComex, the exporter had already prepared all the logistics of delivery of goods, both within the country of manufacture and at the delivery of the goods.

This lack of communication led to uncertainties such as the collection of new information. Thus, a miscommunication led to a corrective action that would not have needed to be done if they had had the information earlier.

Also noteworthy, it is that there are no scheduled meetings between companies to assess the situation and reset procedures, based on the information gathered with the GeoComex CEO. Here we highlight the importance of monitoring meetings. Because they do not usually occur, and thus applied corrective action. 


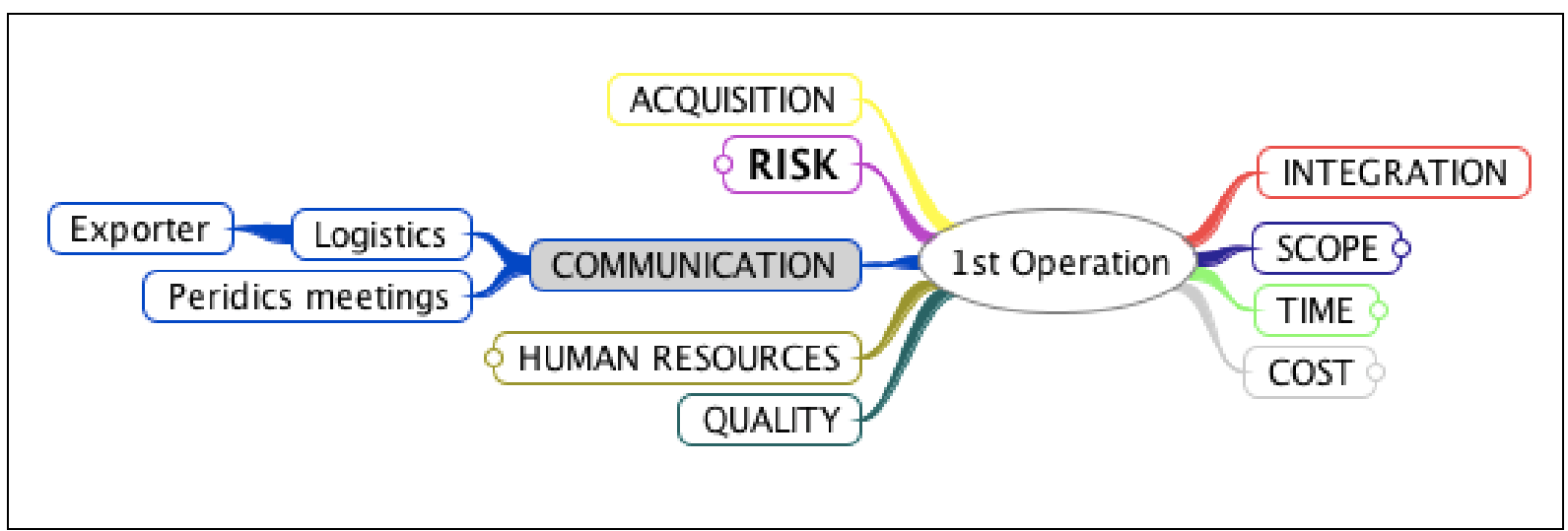

Figure 11: Communication flow of the first process.

\section{a.6) Risks}

The figure 12 depicts the situation where there is lack of important information such as the logistics goods delivery, which may pose risks to the operation, although it has been checked and confirmed that there were no major problems, one realizes that the omission or forgetting a piece of information can become a danger to the validation or not of the operation.

There is still the risk that happened to the petition for authorization of the conference in the establishment of the imported goods, since the operation began in December 2011 and the petition to request authorization was only presented to the Federal Revenue in early first week of January 2012, with authorization approval in the second week of February 2012.

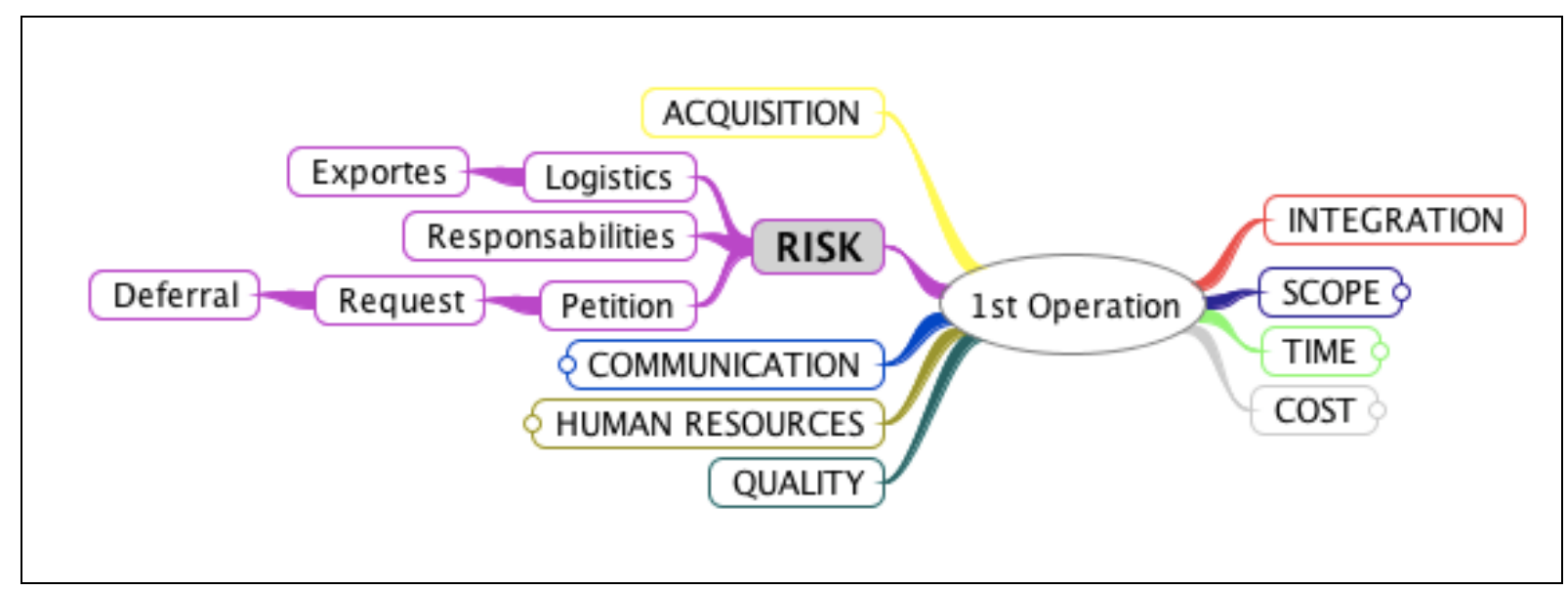

Figure 12: Flow Risk of the first process.

\section{b) Second Operation}

Also at the end of September 2011, the second operation began, from Europe, which has approximately 124735 tons in gross weight. It arrived through the port of 
Santos in early December 2011, and was taken to the town where the factory is being built.

\section{b.1) Scope}

Wasn't a creation of a WBS, so we could not verify whether the processes were done at the correct time? Monitoring was done based on the set time, ie, when the trucks leave Santos with destination to where they would be released, made an estimate time, that if not met, would know that there would be delay, thus increasing the risks, delivery costs and qualities (see Figure 13).

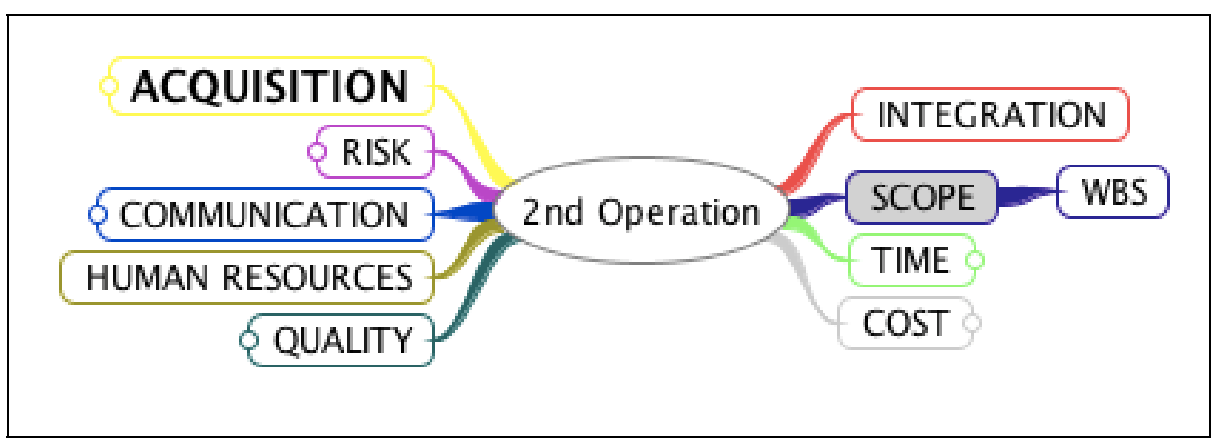

Figure 13: Scope Flow of the second process.

\section{b.2) Time}

There was inclusion of a gap (extra time) in the delivery and release of the merchandise, that is, it was told that there was no problem in this process. But not always when the truck arrived, it was cleared to leave the goods in the factory plant and return to Santos and take the next batch (see Figure 14).

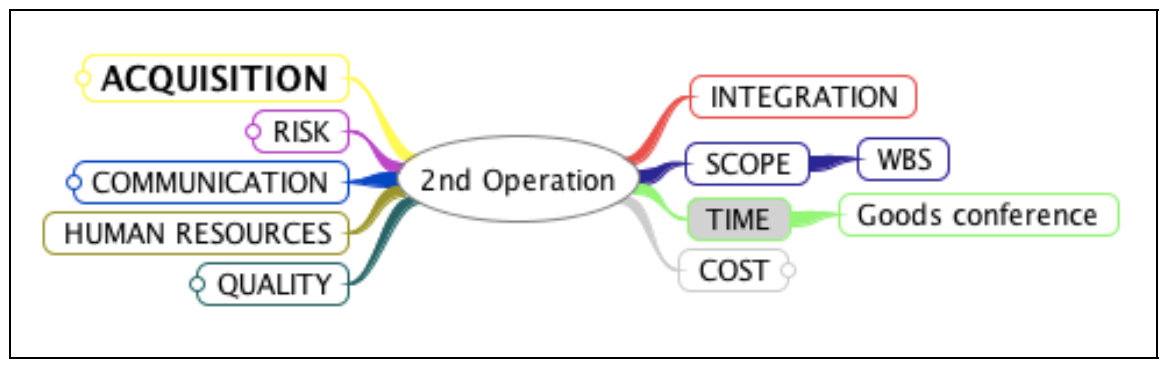

Figure 14: Time Flow of the second process.

\section{b.3) Cost}

With IRS delay in releasing the trucks, there were costs that were not anticipated as the driver's stay, among others. The delay in the release of the trucks 
that would return to Santos, delays the next batch; thus eventually increasing the storage amount of the second batch to be transported (see Figure 15).

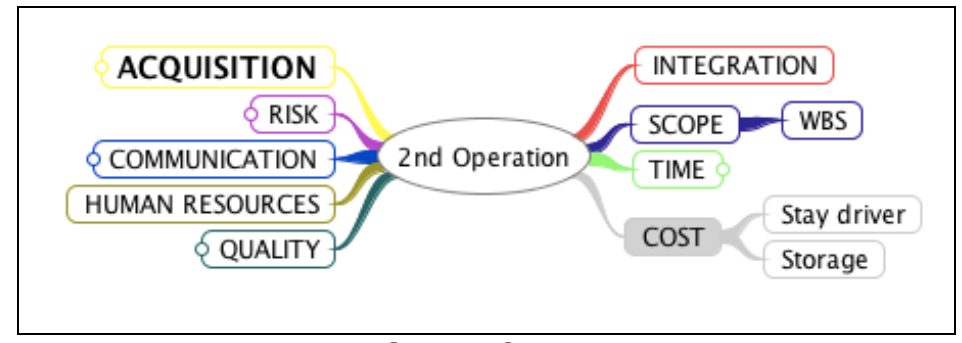

Figure 15: Flow Cost of the second process.

\section{b.4) Quality}

As there was no definition of time, with the beginning and end of the process, it will be much more difficult to endorse the service that was delivered with quality or not. Because the quality (see Figure 16) of the provision of services in logistics, is evaluated based on the time and cost versus planned done.

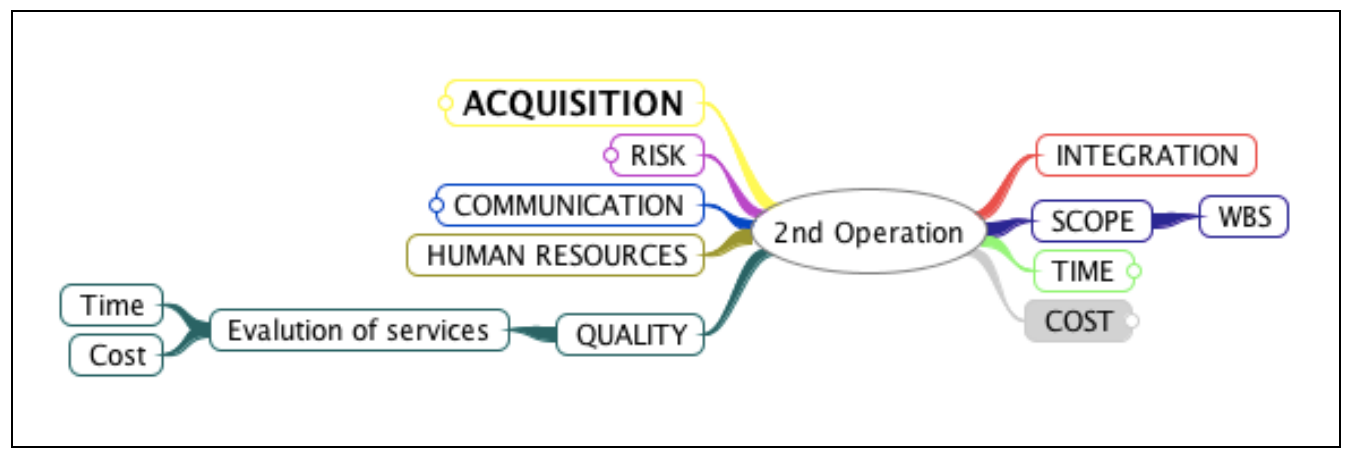

Figure 16: Quality Flow second process.

\section{b.5) Communication}

The lack of definition of roles and responsibilities in the process, can generate major disruptions, such as occurred where the person A was hoping that person B shedualed a date with the IRS to check the goods, but B did not the schedule hoping A would. The lack of communication (see Figure 17) between the two should not have been defined by whom this responsibility belongs to.

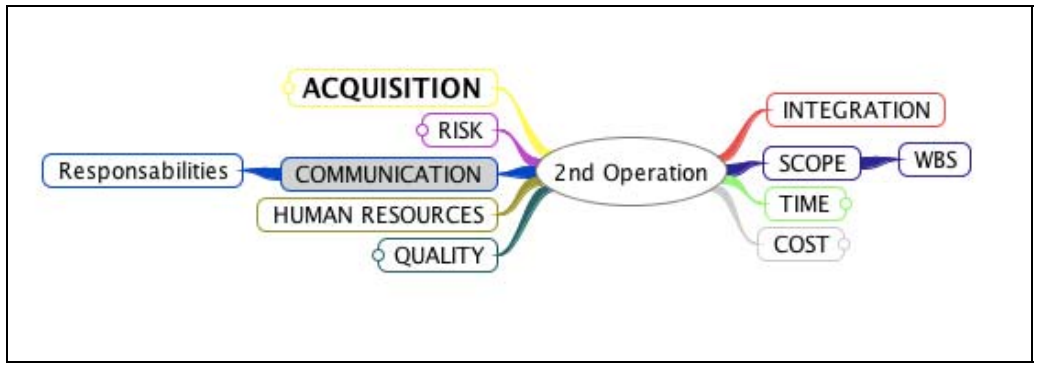

Figure 17: Communication Flow of the second process.

[http://creativecommons.org/licenses/by/3.0/us/]

Licensed under a Creative Commons Attribution 3.0 United States License 


\section{b.6) Risks}

Regarding the petition for authorization of checking of goods in the importer's establishment, it was found that the documentation had not informed that the Federal Inland Revenue what would be the time to move all the cargo in the country of origin to Brazil, and moving the same to the factory plant. Thus, at any moment, there could be a notification from the Federal Revenue.

The delay in clearance of goods, which are not planned delay in this process and where there was a lack of fiscal, rain made it impossible to check, among other issues, which have generated unforeseen expenses and time exceeded.

There were also problems with the amount of trucks for transportation of parts and pieces, because even though the group with more than 150 trucks, they were not enough, thus it was necessary to the return to get the second batch of merchandise.

At the exit of the warehouse in Santos, one of the drivers noticed that the container he was carrying was shaking, i.e., the part was loose, as promptly warned the head of the project at GeoComex, who immediately contacted the store asking for the return of truck and that should be tied again (see Figure 18).

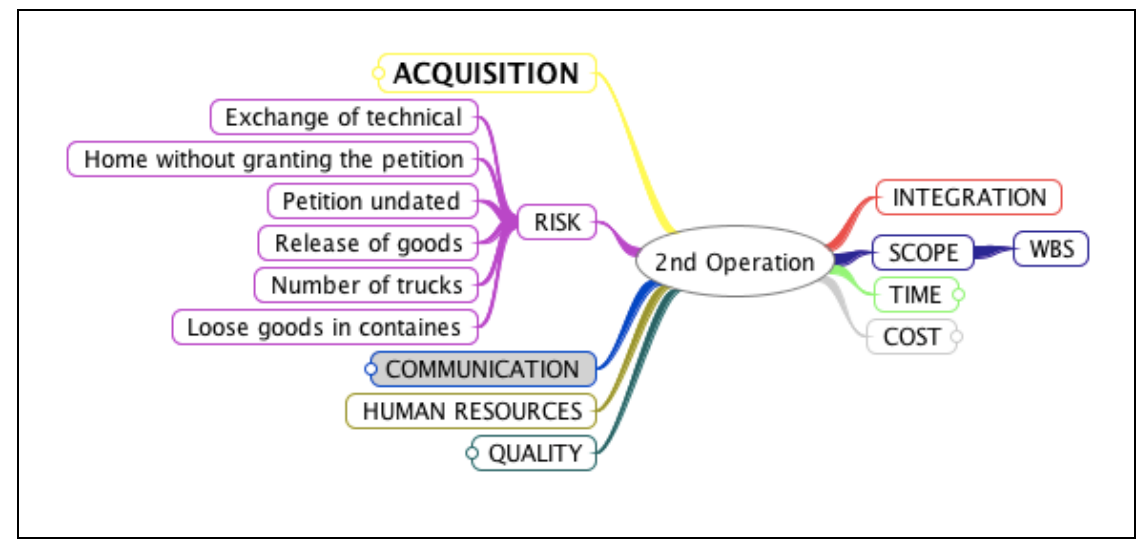

Figure 18: Flow Risk of second process.

\section{b.7) Acquisition}

There was no acquisition (see figure 19) of specific equipment for handling parts, parts bins, and thus some trucks waited until it was possible to remove the goods from above, and return to transport next batch. 


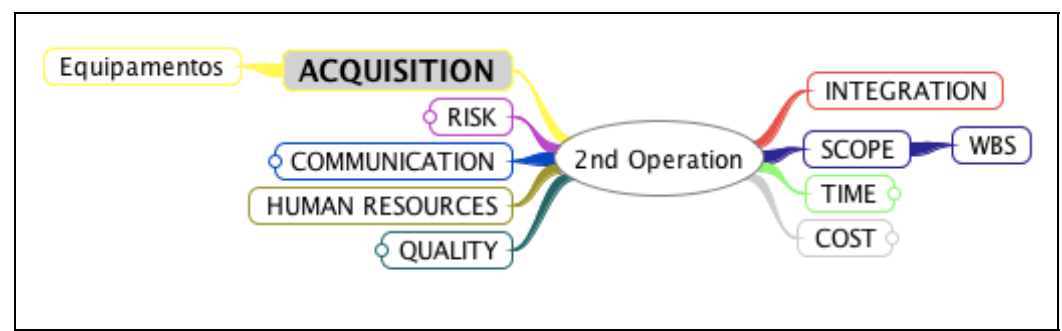

Figure 19: Acquisitions Flow second process (equipment in Portuguese).

\section{DISCUSSIONS}

After doing a series of interviews using the Delphi technique with those involved in the GeoComex company project, the implementation of the company's first plant Spratill; it was observed that the responsibility was well fulfilled. But the question of time and cost was not met due to not having devised a WBS including a planned gap.

In addition, some of the risks identified in the two operations was caused by lack of communication, both in responsibilities, not as well designed, as the disregard of information that were seemingly simple, as logistics made by the exporter, in which GeoComex would only follow. But it could bring big trouble to Spratill, which can be reversed in time.

One can also see the other point in which corrective actions were taken, in which the displacement of people was necessary, generating costs, while they could devote to another part of the project if there was more integration between simple information.

It can be observed that not all aread were worked on by the project management, in which all the information is connected at some point in the project, for example, to demand support from someone who did not received them, among others, not being applicable to the analyzed process.

The GeoComex did not systematically define adjustments for meetings and alignment of actions taken. It was used for meetings, only to deal with problematic or contractual situations. The previously posted comments, are shown in Figure 20, which shows the flow of some failures in the development of the project, which could have been avoided or minimized. 


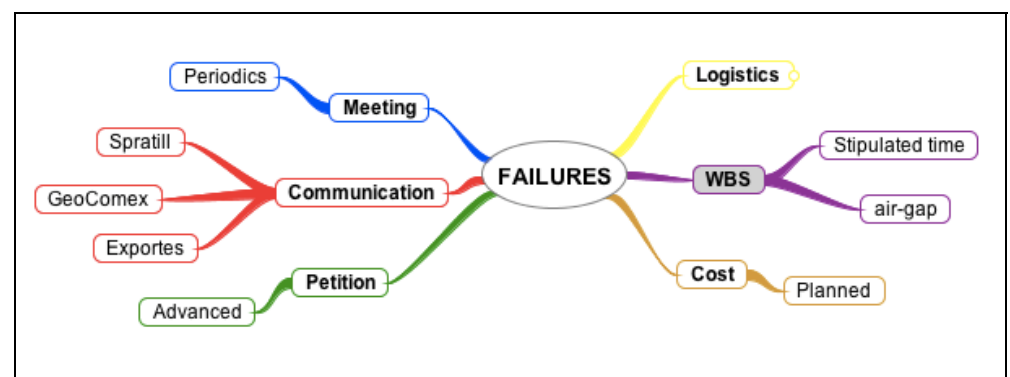

Figure 20: Failure flow of project. Source: The authors.

The implementation of the operation of the company in Brazil handled from start to finish more than 300 trucks from the port of Santos to the location where the Spratill plant was installed.

It was not an easy nor uneventful best scenario within the project, but was completed successfully despite having some problems, particularly due to the conditions of the roads, which were in poor condition. As well as, the issue of low river bed, not allowing the modal rainfall at a given moment.

\section{CONCLUSIONS}

We conclude that the Mind Map is a tool with application to improvement of planning. It is important when you have the knowledge and the form of its implementation, which results in a more comprehensive view of the process, and we could visualize potential failures, thus working with preventive and not corrective actions. The Mind Map can be applied to the management of logistics projects, facilitating the visualization of all necessities for the proper development of each stage of the project through keyword topics, multiplying with ramifications of their exponential, being heightened by the nine areas of project management. After a period of tool use, it can be seen that, as is advocated by Tony Buzan, it acquired knowledge, which tends to be simplified, so the actions to be taken were more visible, both in preventive actions, as the corrective. Possible faults tend to minimize, when looking at the project as a whole, and from different angles, in a systemic way. In the year 2014 the company started its operations so you can put into practice the project of export production. 


\section{REFERENCES}

ARLBJøRN, J. S.; PAULRAJ, A. (2013) Special topic forum on innovation in business networks from a supply chain perspective: current status and opportunities for future research. Journal of Supply Chain Management, p. 3-12.

ARSHINDER, A. K.; DESHMUK, S. G. (2008) Supply chain coordination: perpectives, empirical studies and research directions. International Journal of Production Ecomics, v.115, p. 316-335.

BALLOU, R.; STEPHEN, G.; ASHOK, M. (2000) New managerial challenges form supply chain opportunities. Industrial Marketing Management, v. 29, n. 1, p. 7-18.

BAINES, TIM; LIGHTFOO, HOWARD W. (2014). Servitization of the manufacturing firm Exploring the operations practices and technologies that deliver advanced services. International Journal of Operations \& Production Management, v. 34 n. 1, p. 2-35.

BARRAT, M. (2004) Understanding the meaning of collaboration in the supply chain. Supply Chain Management: An International Journal, v. 9, n. 1, p. 30-42.

BATH, JOHANNA; ÖZTÜREN, ALI. (2013). Impact Factors on Collaboration and Delivery Success in Professional Service B2B Supply Chains. Asian Social Science, v. 9, n. 11.

BOWERSOX, D. J., CLOSS, D. J.; STANK, T. P. (1999) 21st Century Logistics: Making Supply Chain Integration a Reality. Council of Logistics Management, Michigan State University, East Lansing, MI.

BREDILLET, C. N. (2008) Learning and acting in project situations through a metamethod (MAP) a case study: Contextual and situational approach for project management governance in management education. International Journal of Project Management. n. 26, p. 238-250.

BREWER, B. L.; ASHENBAUM, B.; JOSEPH R. CARTER, J. R. (2013) Understanding the supply chain outsourcing cascade: when does procurement follow manufacturing out the door? Journal of Supply Chain Management, p. 90-101.

BUZAN, T. (1995) The Mind Map Book. 2nd edn., BBC Books: London.

BUZAN, T. (1974) Using Both Sides of the Brain. Dutton: New York.

BUZAN, T. (2005) The Power of Creative Inteligence. Harper Collins Publishers Ltd.

CAI, J.; MAB, X.; LI, Q.; LI, L.; PENG, H. (2009) A multi-objective chaotic particle swarm optimization for environmental/economic dispatch. Energy Conversion and Management. v. 50, p. 1318-1325.

CALAZANS, ANGÉLICA TOFFANO SEIDEL; KOSLOSKI, RICARDO AJAX DIAS; RIBEIRO JUNIOR, LUIZ CARLOS MIYADAIRA. (2012). Proposal for a measurement model for software tests with a focus on the management of outsourced services. JISTEM - Journal of Information Systems and Technology Management. Revista de Gestão da Tecnologia e Sistemas de Informação. v. 9, n. 2, May/Aug. 2012, p.265-284 
CAO, Q.; HOFFMAN, J. J. (2011) A case study approach for developing a project performance evaluation system. International Journal of Project Management, n. 29 , p. $155-164$.

CLAUSS, M.; MÜLLER, D. W. H.; CODRON, D. (2013) Source References and the Scientist's Mind-Map: Harvard vs. Vancouver Style. Journal of Scholarly Publishing, v. 44, n. 3, p. 274-282.

COELHO, L. S.; LEE, C. S. (2008) Solving economic load dispatch problems in power systems using chaotic and Gaussian particle swarm optimization approaches. Electrical Power and Energy Systems. v. 30, p. 297-307.

EISENHARDT, K. M. (1989). Building theories from case-study research. Academy of Management Review, n. 14, p. 532-550.

EPPLER, M. J. (2006) A comparison between concept maps, mind maps, conceptual diagrams, and visual metaphors as complementary tools for knowledge construction and sharing. Information Visualizatio, n. 5, p. $202-210$.

FAWCETT, S. E.; MAGNAN, G. M. (2002) The rhetoric anda reliability of supply chain integration. International Journal of Phsysical Distribution \& Logistics Management, v. 32, n. 5, p. 339-361.

FEDERAL REVENUE OF BRAZIL (2012) Portuguese. Customs Clearance of Import.

Available:

<http://www.receita.fazenda.gov.br/aduana/procaduexpimp/despaduimport.htm>.

Access: 09/02/2012.

FORTUNE, J.; WHITE, D. (2006). Framing of project critical success factors by a systems model. Int. J. Project Manage. v. 24, n. 1, p. 53-65.

GAREL, G. (2013) A history of project management models: From pre-models to the standard models. International Journal of Project Management. n. 31, p. 663-669.

GARCIA, R. S.; WEISSERB, D. (2006) A wind-diesel system with hydrogen storage: Joint optimisation of design and dispatch. Renewable Energy. v. 31, p. 2296-2320.

GLASER, B. G.; STRAUSS, A. (1967). Discovery of Grounded Theory: Strategies for Qualitative Research. Sociology Press, Chicago.

HAN, X. S.; GOOI, H. B. (2007) Effective economic dispatch model and algorithm. Electrical Power and Energy Systems. v. 29, p. 113-120.

JAYARAM, J.; TAN, K. C. (2010) Supply chain integration with third-party logistics providers. Int. J. Production Economics. v. 125, p. 262-271.

JOHNSON. S. B. (2013) Technical and institutional factors in the emergence of project management. International Journal of Project Management. n. 31, p. 670681.

KERZNER, H. (2004). Advanced Project Management: Best Practices on Implementation. John Wiley \& Sons.

KONONENA, D. W.; FLANNAGANB, C. A. C.; WANG, S. C. (2011) Identification and validation of a logistic regression model for predicting serious injuries associated with motor vehicle crashes. Accident Analysis and Prevention. v. 43, p. 112-122.

LEWIS, J. P. (2000). The Project Manager's Desk Reference. McGraw-Hill, New York. 
LUMMUS, R. R.; VOKURKA, R. J. (1999) Defining supply chain management: a historical perspective and practical guidelines. Industrial Management \& Data System, v. 99, n. 1, p. 11-17.

MARQUES, G.; GOURC, D.; LAURAS, M. (2010) Multi-criteria performance analysis for decision making in project management. International Journal of Project Management, n. 29, p. 1057-1069.

MENTZER, J. T.; DEWITT, W.; KEEBLER, J.; MIN, S.; NIX, N.; SMIITH, C.; ZACHARIA, Z. (2001) Defining supply chain management. Journal of Business Logistics, v. 22, n. 2, p. 1-25.

MINTZBERG, H. (1994) The Fall and Rise of Strategic Planning. Havard Business Review, Prentice-Hall, Inc. p. 107-114.

OJIAKO, U.; ASHLEIGH, M.; CHIPULU, M.; MAGUIRE, S. (2011) Learning and teaching challenges in project management. International Journal of Project Management, n. 29, p. 268-278.

OZGEN, A.; TANYAS, M. (2011) Joint selection of customs broker agencies and international road transportation firms by a fuzzy analytic network process approach. Expert Systems with Applications. v. 38, p. 8251-8258.

PENEDER, M. (2008) The problem of private under-investment in innovation: A policy mind map. Technovation. n. 28, p. 518-530.

PORTER, M. E. (1998). Clusters and the new economics of competition. Harvard Business Review, v. 76, n. 6, p. 77-81.

PORTER, M. E. (1988) Competitive Advantage: Creating and Sustaining Superior Performance. Nova York: Free Press.

PORTER, M. E. (2000). Location, competition, and economic development: local clusters in a global economy. Economic Development Quarterly, n. 14, p. 15-34.

PORTER, M. E. (1990). The Competitive Advantage of Nations. The Free Press, New York.

REICH, B. H.; GEMINO, A.; SAUER, C. (2012) Knowledge management and projectbased knowledge in it projects: A model and preliminary empirical results. International Journal of Project Management. n. 30, p. 663-674.

RIGGS, W. E. (1983) The Delphi Technique An Experimental Evaluation Technological. Forecasting and Social Change, n. 23, p. 89-94.

RODRIGUES, J. P. (2012) The geography of global supply chains: evidence from third party logistics Journal of Supply Chain Management. p. 15-23.

ROSENBAUM, P.; RUBIN, D. (1983). The central role of the propensity score in observational studies for causal effects. Biometrika. n. 70, p. 41-55.

ROWE, G.; WRIGHT, G. (1999) The Delphi technique as a forecasting tool: issues and analysis International. Journal of Forecasting, n. 15, p.353-375.

ROWE, G.; WRIGHT, G. (2011) The Delphi technique: Past, present, and future prospects. Introduction to the special issue Technological. Forecasting \& Social Change, n. 78, p. 1487-1490. 
SAMARANAYKE, P. (2005) A conceptual framework for supply chain management: a structural integration. Supply Chain Management: An International Journal, v. 10, n. 1, p. 47-59.

TAKEDA, Y.; KAJIKAWA, Y.; SAKATA, I.; MATSUSHIMA, K. (2008) An analysis of geographical agglomeration and modularized industrial networks in a regional cluster: A case study at Yamagata prefecture in Japan. Technovation. v. 28, p. 531539.

YAGHOOTKAR, K.; GIL, N. (2012) The effects of schedule-driven project management in multi-project environments. International Journal of Project Management, n. 30, p. 127-140.

YIN, R. K. (1994). Case Study Research: Design and Methods. Sage Publications, Thousand Oaks, California.

YU, A., FLETT, P., BOWERS, J. (2005). Developing a value-centred proposal for assessing project success. Int. J. Project Manage, v. 23, n. 6, p. 428-436. 